\title{
EFFECTS OF CONTEXT FACTORS ON POST-SUCCESSION PERFORMANCE OF FAMILY BUSINESSES IN NIGERIA
}

\author{
PAUL, Vincent ${ }^{1}$; ABUBAKAR, Lamino Hauwa ${ }^{2}$;BRAHIM, Hauwa Victoria ${ }^{3}$; OBERE, \\ Yahaya Muhammad ${ }^{4}$ \\ ${ }^{1}$ Department of Entrepreneurship Studies, Nasarawa State University, Keffi \\ ${ }^{2}$ Department of Business Administration, Faculty of Management Sciences, Nile University of Nigeria, \\ Jabi,-FCT. \\ ${ }^{3}$ Department of Entrepreneurship Studies, Nasarawa State University, Keffi \\ ${ }^{4}$ Department of Business Administration, Nasarawa State University, Keffi
}

DOI: 10.46609/IJSSER.2020.v05i09.017 URL: https://doi.org/10.46609/IJSSER.2020.v05i09.017

\begin{abstract}
This study surveyed the effect of context factors on post-succession performance of family businesses in Nigeria on post-succession performance of family businesses in Nigeria. In the study, post-succession performance were measured by successor understanding of business context, comprehensive perception of business cycle and environment and monitoring employee while survey design was adopted as research design. The population of the study is eight hundred and fifty eight (858) family businesses selected in Nigeria. The whole numbers of selected businesses were used as the target population for the study. The data collected were tested for reliability. The result of the reliability indicates a Cronbach Alpha of $82 \%$ which implies that the instrument was capable of measuring the views of the respondents with consistency. The data collected were analyzed using regression techniques. The analysis was done for each zone and their combined effects using panel regression. The study found that a unit increase in the level of successor understanding of the business results will increase performance. Also, increase in comprehensive perception of business cycle and environment and monitoring of employee will increase performance. In line with the findings and the conclusion above, the study thus recommends that successors should equip themselves with the understanding of the business environment and its cycles as well as ensuring that the right people are in charge through careful search and proper placement in strategic positions of the business. This will lead to a better focus thus resulting in improved performance and development of the businesses.
\end{abstract}




\section{International Journal of Social Science and Economic Research}

ISSN: $2455-8834$

Volume:05, Issue:09 "September 2020"

Keywords: Context Factors, Family Business, Performance, Post-Succession

\section{Introduction}

Context factor is the factor associated with changes in the economic environment that has effect on family business operation such as change in business performance and the loss of major key customers or suppliers of the enterprise especially when the changes are negative. On the other hand, when the changes are positive, it result to increase in output of the family business activities. In this research, context factors refer to the related aspects of the succession process that might prevent the succession from taking place which will equally affect the post-succession performance of the family business enterprise. The economic environment can influence succession because of some contingency and uncertainty in the business environment. Changes in the business environment and market conditions can alter the future prospects of the family business to strive maximally. If changes in the market conditions increase, there is probability for business failure, then the incumbent is less likely to transfer the business to his or her potential successor who would also be assessed or evaluated after assuming the leadership responsibilities of the family firm.

The uncertainty on this ground will create pressure for the incumbent to sell the firm instead of transferring the leadership of the business to a family successor, thereby taking the firm away from the family completely to those who are financially buoyant and otherwise (Carlock \& Ward, 2001; Cespedes \& Galford, 2004; Venter, Boshoff, \& Maas, 2005). Moreover, the size of the business also matters in terms of succession and post-succession. The larger the size of the firm, the higher the chance that the offspring will join the business and will be certainly trained to take over the business in the nearest future. Therefore, the smaller the size, the higher the chance that the potential successor will leave the family business due to possibly unattractive monetary rewards that will not meet up the expectation of the successor and other stakeholders of the family firm Venter, Boshoff and Maas (2005).

A firm's environmental strategy refers to a firm's strategy to manage the interface between his business and natural environment of operation (Kanter, 2009). Family involvement and unique family dynamics impact organizational strategy and performance of the family business enterprise (Sharma \& Sharma, 2011). Environmental strategies focus on meeting legal requirements and implementing pollution controls to allow businesses operate without hindrances in terms of cleanness of the environment. Family businesses pursuing such strategies are driven by instrumental factors such as avoiding legal sanctions or penalties and negative impacts on a firm's image or reputation that will bring the struggle and the good image of the family to nothing and therefore, render them incapable and acceptable in the society (Russo \& Fonts 1987: cited in Sharma \& Sharma, 2011). 


\section{International Journal of Social Science and Economic Research}

ISSN: $2455-8834$

Volume:05, Issue:09 "September 2020"

Sharma and Sharma (2011), argued that family involvement in business influence the attitudes, subjective norms and perceived behavioural control of a firm's dominant coalition. In non-family firms, it is very difficult to link individual level beliefs, values and attitude with organizational level strategy without examining processes that translate these beliefs into deep rooted and pervasive organizational and cultural change. In contrast, in family firms, the long tenure of the family leadership and the controlling family influence on the firm's dominant coalition allow easier spread of individual and family values into the firm's resource allocation decision such that everything is done with the considerations of family integrity and the business values (McConaughy, 2000)

Family business is the main source of income for the family members therefore; any changes in the business environment will definitely affect the performance of the business during and after post-succession. One of the most positive qualities of family enterprises is their short decisionmaking chain, which secures rapid implementation of family and business objectives.

Factors influencing the activity and success of family businesses are the mutual relationships between family members and a detailed and well considered strategic action plan as well as organizational culture. A family business strategy is specifically planned in such a manner that all tasks must be carried out consistently and persistently to meet the needs of the stakeholders. The organizational culture and strategic planning process in a family business never ends, there must be continuous adjustment to changes that will occur based on the business environment. Family business entrepreneurs believe that with a strong family and proper strategic management, they can ensure achievement of the objectives no matter the turbulence of the business environment Kirsipuu (2011).

This study aimed at evaluating the effects of context factors on post-succession performance of family businesses in Nigeria and to determine how factors involvement can build or mar the family enterprises.

\section{Literature Review}

\section{Concept of Context Factor}

Context factors are part of the major features that affect the succession and post-succession performance of family businesses within and around the world. Chaimahawong and Sakulsriprasert (2012b) viewed contextual factors in relation to family business as those factors that are associated with changes in the economic environment of where business activities are taking place which also has effects on family business succession and post-succession performance. These changes in the macro or micro environment of the business can influence either positively or negatively the succession process and the post-succession activities of the 


\section{International Journal of Social Science and Economic Research}

ISSN: $2455-8834$

Volume:05, Issue:09 "September 2020"

family businesses. De Massis, Chua, and Chrisman (2008); Wang (2010) in their studies, they identified two categories of context factors which are classified as macro context and this includes societal and cultural contexts and micro context which comprised of individual and family contexts.

Breton_Miller, Miller and Steier (2004) on their part, suggested that succession is a social and family process influenced by cultural circumstances and social context of the existing family business. Based on this view, Georgiou and Vrontis (2013) viewed and summarized contextual factors from the submission of other scholars into the following components as family dynamics, board of directors, incumbent-successor expectations, organizational performance, transfer of capital, organizational size and age, succession monitoring and reflective feedback. It has been proved that with regards to individualism and collectivism paradigm, individualistic oriented people will always tend to interpret and handle both family and business issues differently from collectivistic oriented people (Ye, Parris, \& Waddell, 2013; Colot \& Bauweraerts, 2014).

\section{Successor Understanding of Business Context and Its Impact on Family Business}

The need for a successor to understand family business operations particularly before, during and after planning for transfer and change of leadership is of paramount importance to all businesses especially, the family-owned firms. The successor understanding of the business must covers factors such as the family culture or tradition where the successor need to recognize and respects the values of the family; the business culture which is considered as the organizational culture must also be observed by the successor. On this aspect, the concept of organizational culture is an intangible phenomenon which has become an important part of the organizational life cycle of any existing and functional organization as it happened in the past few decades and still in place till date (Mohelska \& Sokolova, 2015; Leithy, 2017).

Business organizational culture can be described as a framework of shared cognitive values such as attitudes, beliefs, norms, habits, expectations, collective thoughts and behavioral patterns amongst members and employees of a given business organization such as the case of familyowned firms.

For many businesses in the world, the origin of an organizational culture amongst can be attributed to both internal and external factors such as employee attitudes and beliefs to work and other factors, industry in which the organization operates and the attitudes and beliefs of the organizations management and stakeholders. Other external factors which influence the origin and style of organizational culture can be attributed to the historical events surrounding the business and the geographical location as well as the immediate environmental factors around the business (Mohelska \& Sokolova, 2015 in Lu \& Visser, 2019). 


\section{International Journal of Social Science and Economic Research}

ISSN: $2455-8834$

Volume:05, Issue:09 "September 2020"

The role of organizational culture in business has been ascribed to the positive effect it has on employees, organizational processes and key stakeholders which a successor of a family-owned business should honour in a high esteem (Leithy, 2017). Although not a guarantee for success, the role of organizational culture can have a significant effect on the effectiveness and efficiency of a business, and its positive effects have become a highly sought-after concept for successful management of existing and functional business enterprise (Mohelska \& Sokolova, 2015). Researches in the past has linked the effects of a strong organizational culture with high levels of innovation and through that engagement, there is also high levels of business performance (Gopalakrishnan \& Zhang, 2017).

High levels of innovation in a strong organizational culture has been accredited to higher levels of employee retention, job satisfaction by the employees, organizational commitment and organizational identification by and in around (Green \& Cluley, 2014; Gopalakrishnan \& Zhang, 2017). However, organizational culture is not only important for a firm's innovation and performance rather, it is also viewed as an important for understanding how employees work together and how cooperation between employees and management of a business affects why and how an organization successfully achieves innovation and performance of the firms or why and how an organization unsuccessfully does not achieve innovation and performance of the business (Green \& Cluley, 2014; Farrell, 2018). Mainly, organizational cultures are influenced and piloted by leaders who use organizational culture as a means to build and address issues in innovation, and to implement changes that will bring development when necessary through the adoption of organizational culture as a tool to influence followers to do the needful (Farrell, 2018).

\section{Monitoring of Employees and Its Influence on Family Business Performance}

In monitoring employees of family-owned, operated businesses, the leadership and management culture of the given family business enterprise must critically be acknowledged. Taking into account the leadership role and organizational culture, effective leadership is seen as key to influencing a positive organizational culture and family business performance. Organizational culture is significant to understanding the cooperation between employees, owners and management of family businesses; however, the role of leadership in organizational culture is to direct followers in obedience to the culture and to influence followers to contribute their own part to the organizational growth and development (Farrell, 2018). Again, the pattern of positive organizational culture and the influence it has on family and their business performance through employees contribution is very fundamental (Green \&Cluley, 2014) (Gopalakrishnan \& Zhang, 2017). In addition to positive organizational cultures, the role of leaders is to contribute and build the organizational culture which supports the core values of family firms that can lead to achievement of future goals through good leadership initiatives and strategies (Farrell, 2018). 


\section{International Journal of Social Science and Economic Research}

ISSN: $2455-8834$

Volume:05, Issue:09 "September 2020"

The manager of a family business may also be unable to resist relatives as employees working for the family company; this is regardless of their lack of qualifications. These relatives who are allowed into the company may abuse family ties and feel that they cannot be held responsible for anything and therefore simply under-perform because they are a relative to the proprietor of the family business. Some family members, especially the elderly, may also find it difficult to retire or quit and let the younger talented members take over. This may also affect the morale of nonfamily employees who may think they are being undermined since they do not receive enough reciprocity for the efforts or appreciation for their input (Caroline, 2014).

According to Loiseau (2011), employees are to an organization the most valuable asset; therefore, management should ensure that employee advancement of people in the workplace is the fundamental part of all management process. To understand the critical importance of people in an organization it is necessary to have an inclusive harmonization between the human element and the organization itself. In fact, many well-managed organizations learn to consider an average worker as the root source of quality and productivity gains. Depend on the size; many of such organizations do not look to capital-investment, but to employees, as the fundamental source of improvement. Dynamic managers with knowledge about what motivates people have at their command the most powerful tool to achieve extraordinary results. When companies are effective in satisfying their employees advancement, Employees arm themselves with an extraordinary level of confidence that induce them to stay longer, make a deeper commitment to the business, recommend ways to improve the company's services or products, and work harder to satisfy the customers and stakeholders (Loiseau, 2011).

Employee advancement after training leads to the development of new skills and competencies; increased job satisfaction (more challenging work, greater variety and many others) aligning work with personal values and motivations; provides a map for employees to see how they might be able to move laterally or vertically in the organization; provides individuals with a degree of influence and control over the direction of their careers and an ability to identify and plan their development. Indeed it is argued further that employee advancement makes it possible for an organization to have a well-motivated workforce - and this creates among others: improved ability of managers to plan ahead for the staffing of key positions (succession planning); better identification of the organizations workforce planning needs; increased staff morale through a sense of development and feeling valued; lower staff turnover levels and a more stable workforce; increased internal recruitment activity (rather than external), and the associated cost savings; retention of more experienced and skilled staff and improved level of service to people with a disability and families. It should be noted, however, that some organizations prefer external recruitment in a bid to select the best person for the job. 


\section{International Journal of Social Science and Economic Research}

ISSN: $2455-8834$

Volume:05, Issue:09 "September 2020"

Armstrong (2009) agrees with this and notes that people are motivated when they expect that a course of action is likely to lead to the attainment of a goal and a valued reward - one that satisfies their needs like employee advancement in career. He goes even further to assert that the organization can provide the framework that can facilitate high levels of motivation through the provision of incentives and rewards, satisfying work and opportunities for learning and growth.

The managers role here, in motivating employees to perform cannot be overemphasized. Nomura Research Institute Ltd (2005) points out that rewards are vital for staff acquisition and retention.

Armstrong (2009) concurred and agreed that promotion is necessary for job satisfaction and that it stands for increased incentives in recognition of the employees' performance and contribution. Nomura Research Institute Ltd (2005) agreed that employee advancement and reward systems are sources of motivation at the work place. It is, therefore, logical to believe that there may be a negative impact on motivation, morale, job satisfaction and performance in organization.

\section{Perception of Business Cycle and Environment of Family Business}

A cycle consists of expansions occurring at about the same time in many economic activities, followed by similarly general recessions, contractions, and revivals which merge into the expansion phase of the next cycle of a business; this sequence of changes is recurrent but not periodic; in duration business cycles vary from more than one year to ten or twelve years (Dekimpe \& Deleersnyder, 2018). Importantly, these cycles are visible across multiple aggregate economic series such as real Gross Domestic Product (GDP) of a country of operation, real income, or employment, among others (Stock \& Watson 1999).

Erven (2019) opined that understanding the family business environment starts the process of success with family labour. The family business environment typically has the following key characteristics: i. the family and the business overlap. Family considerations affect many business decisions; for example, business expansion is justified by a son's interest in the business. ii. The small business way of life brings great satisfaction to family members. Many families want to continue their attachment to the business and each other as long as possible. Children grow up wanting to raise their children the way their parents raised them. iii. Family pride, values, history, and willingness to sacrifice drive the business to success. The family business is much more than a business. It is often a family's identity in the community. Family members are willing to sacrifice much for the success of the business. iv. The family culture emphasizes self-employment. Most owners highly value self-employment. Not surprisingly, their children are often raised to prefer self-employment over working for someone else, especially a neighboring business. $\mathrm{v}$. The opportunities provided by a small business may not fit the strengths of family members. The strengths of younger siblings in the management of crops, machinery, or 


\section{International Journal of Social Science and Economic Research}

ISSN: $2455-8834$

Volume:05, Issue:09 "September 2020"

sales often duplicate the strengths already in the business. An answer to the desperate need for strengths in financial management, marketing, or labor management may be nowhere to be found among family members in the business.vi. The family business often limits the opportunities for career growth. A capable young family member often joins a family business while his or her parents are in the middle of their careers. Grandparents may still play a dominant role. In this situation, reality is waiting 30 years for one's first significant taste of top management decision making. Vii. Chronic health problems, weather, marital problems, economic difficulties, and calamities impede progress of the business. viii. Family members often come into the business with vague job descriptions, compensation packages, and placement in the business hierarchy with the confidence that everything will work out substitutes for careful discussion of the pros and cons for joining the business. Growing up in the business or marrying into it leads to the conclusion that not much can or will change the situation of the business activities and many others (Erven, 2019).

\section{Concept of Family Business}

Family business is described as a firm (s) that constitute the easiest and dominant as well as the oldest form of business organizations, and are crucially important in economies of countries and the world in general (Zahra, Hayton, \& Salvato, 2004; Comi \& Eppler, 2014). In most countries, family firms play a key role in overall economic development, including employment creation and workforce engagement. Understanding of family firms ranges from small enterprises serving a neighborhood of various communities, to large conglomerates that operate in multiple industries in and around countries of the world (IFC, 2008).

Chua, Chrisman and Sharma (1999); Mandl (2008) asserted that what distinguishes a family business uniqueness is the model of ownership, governance, and succession management that materially affects the objectives, strategies, structure, and the way in which it is mobilized, organized, formulated, designed, implemented and owned as business activity.

According to Poza and Daugherty (2013), that if a business is to be considered a family owned venture it must meet the following features: (a) ownership control (15\% or higher) by two or more members of the family; (b) strategic influence by family members on the management of the firm, either by being active in management, continuing to create culture, serving as an advisor or board member, or by being an active shareholder; and (c) concern for family relationships; the dream or possibility of continuity across generations. Further to this list of characteristics, Poza and Daugherty (2013) added several features as: (a) the presence of the family; (b) the overlap of family, management, and ownership, with its zero-sum (win-lose) propensities, which in the absence of growth of the firm, render family business particularly vulnerable during succession; (c) the unique sources of competitive advantage (e.g. a long term 
International Journal of Social Science and Economic Research

ISSN: 2455-8834

Volume:05, Issue:09 "September 2020"

investment horizon), derived from the interaction of family, management, and ownership, especially when family unity is high; and (d) the owner's dream of keeping the business in the family (the objective being business continuity from generation to generation). Alderson (2011) defined a family business as a "business governed and/or managed in order to form and follow the vision of the business and family values held by a dominant coalition controlled by members of the same family or a small number of families that is potentially sustainable in all generations of the family or families."

\section{Methodology}

This study adopts the use of survey research design. This design is employed because the study involves field survey work during the collection of data aided with the use of questionnaire from various states across Nigeria. The population of this study is eight hundred and fifty eight (858) family businesses selected in Nigeria. The whole number of selected businesses was used as the population and the sample size of the study. The data were collected using a five point Likert scale questionnaire. The questions were scaled based on: 5-strongly agreed, 4-agreed, 3undecided, 2-strrongly disagreed and 1-disagreed. The data collected were tested for reliability. The result of the reliability indicates a Cronbach Alpha of $82 \%$ which implies that the instrument is capable of measuring the views of the respondents with consistency.

The data collected were analyzed using frequency counts and percentages while the hypotheses were tested using pooled regression techniques. The analysis was done for each zone and their combined effects using panel regression. The regression models below are used to test the various hypotheses formulated for the study. Two regression models were specified for each of the hypotheses. One of the models was used for regional test while the other is used for the pooled regression model.

The regression model is specified below:

\section{Context Factors and Post-Succession Performance}

$$
\begin{aligned}
& P S P=\alpha+\beta_{1} S U B+\beta_{2} C P C E+\beta_{3} M E+\varepsilon \\
& P S P_{I}=\alpha+\beta_{1} S U B_{I}+\beta_{2} C P C E_{I}+\beta_{3} M E_{I}+\varepsilon_{I} \\
& S U B=\text { Successor Understanding of Business Context } \\
& C P C E=\text { Comprehensive Perception of Business Cycle and Environment } \\
& M E=\text { Monitoring of Employees }
\end{aligned}
$$


International Journal of Social Science and Economic Research

ISSN: 2455-8834

Volume:05, Issue:09 "September 2020"

Table 1: Variables Definition

\begin{tabular}{|l|l|l|l|}
\hline S/N & Variables & Definition & Measurement \\
\hline 1 & SUB & Successor Understanding of Business Context & Likert Scale \\
\hline 2 & CPCE & Comprehensive Perception of Business Cycle and Environment & Likert Scale \\
\hline 3 & ME & Monitoring of Employees & Likert Scale \\
\hline 4 & PSP & Post succession performance & Likert Scale \\
\hline
\end{tabular}

Source: Author's Computation (2019)

Results and Discussion

Table 2: Context factors and Post-succession performance

\begin{tabular}{|c|l|l|l|l|l|l|l|}
\hline Parameters & NC & NW & NE & SW & SE & SS & PANEL \\
\hline C & 0.822053 & 0.731013 & 0.747388 & 0.810437 & 0.714600 & 0.792445 & 0.744682 \\
\hline SUB & 0.149629 & 0.136992 & 0.166193 & 0.191074 & 0.146112 & 0.192113 & 0.172608 \\
\hline CPCE & 0.156943 & 0.162628 & 0.238222 & 0.187109 & 0.172405 & 0.125139 & 0.174167 \\
\hline ME & 0.165521 & 0.255075 & 0.163382 & 0.121694 & 0.164227 & 0.181643 & 0.184840 \\
\hline R-squared & 0.476936 & 0.623630 & 0.595891 & 0.498160 & 0.529463 & 0.607900 & 0.563674 \\
\hline AdjR.sqrd & 0.467866 & 0.618278 & 0.584345 & 0.487329 & 0.513778 & 0.595114 & 0.562097 \\
\hline F-statistics & 52.58124 & 116.5393 & 51.61039 & 45.99366 & 33.75693 & 47.54465 & 357.4155 \\
\hline $\begin{array}{l}\text { P- } \\
\text { Fstatistic }\end{array}$ & 0.000000 & 0.000000 & 0.000000 & 0.000000 & 0.000000 & 0.000000 & 0.000000 \\
\hline
\end{tabular}

\section{Source: Computed Result Using EViews, 2019}

Table above shows the regression result for the link between the explanatory variables of context factors and the post-succession performance of family businesses in Nigeria.

The result indicates that on aggregate level, the value of R-squared and adjusted R-squared are $47 \%$ respectively. This implies that the variables used were able to account for only $56 \%$, the remaining $44 \%$ could be accounted for by other variables not captured in this study. At regional level, the value of adjusted R-squared in the North Central is $46 \%$, NW is $62 \%$, NE is $59 \%$, SW is $49 \%$, SE is $53 \%$, and SS is $60 \%$. 


\section{International Journal of Social Science and Economic Research}

ISSN: $2455-8834$

Volume:05, Issue:09 "September 2020"

The results show that in the absence of the explanatory variables, post-succession performance grows at a constant rate of 0.822 in the $\mathrm{NC}, 0.73$ in the $\mathrm{NW}, 0.74$ in the NE, 0.81 in the $\mathrm{SW}, 0.71$ in the SE and 0.79 in the SS. On the aggregate model, the constant rate of growth is 0.74 .

The results depict that a unit increase in the level of successor understanding of the business results in a 0.14 increase in the $\mathrm{NC}, 0.13$ in the $\mathrm{NW}, 0.16$ in the $\mathrm{NE}, 0.19$ in the $\mathrm{SW}, 0.14$ in the $\mathrm{SE}$ and 0.19 in the SS. For the panel model the increase in performance rate is 0.17 . This rate is higher in the Southern region.

A unit increase in the level of comprehensive perception of business cycles and environment leads to a 0.15 increase in the post-succession performance in the $\mathrm{NC}, 0.16$ in the $\mathrm{NW}, 0.23$ in the NE, 0.18 in the SW, 0.17 in the SE and 0.12 in the SS. The result for the panel model shows a 0.17 increase in the performance level.

For monitoring of employees and its effect on post-succession performance, the result shows that a unit increase in its level leads to a 0.165 rise in the performance in the NC, 0.225 in the NW, 0.16 in the NE, 0.12 in the SW, 0.18 in the SS and 0.164 rise in the SE. All of the variables have statistical significance as their respective p-values are less than $5 \%$.

On the significance of the overall model, the result shows that the p-values of all the regions and the panel model are less than 5\%. This implies that context factors have significant effects on post-succession performance of post-succession of family businesses in Nigeria.

On the deterministic power of contextual factors, the result across all zones and aggregate level showed that factors such as successor's understanding of business context, comprehensive perception of business cycles and environment; and monitoring of employees closely to ensure they perform their responsibilities have significantly effects post-succession performance of family businesses in Nigeria. This finding is collaborated with the works of De Massis, Chua and Chrisman (2008); Chaimahawong and Sakulsriprasert (2013), confirmed that when these factors are keenly taken care of, by the successors and key players in the business, because when they are properly identify and handle well, they help boost the performance of a business venture after succession.

\section{Conclusion and Recommendations}

The study examined the effects of context factors on post-succession performance of family businesses in Nigeria. The key findings of the study show that context factors are determinants of post-succession performance of family businesses in Nigeria and across the world. 


\section{International Journal of Social Science and Economic Research}

ISSN: $2455-8834$

Volume:05, Issue:09 "September 2020"

The study therefore, concludes that context-factors such as the successor's understanding of the businesses, using appropriate mix for each business life cycle and proper monitoring of employees results in improved post-succession performance of the enterprises. This connotes again, that the successor must have the requisite knowledge and the ability to influence people especially customers in order to stick their products by constantly patronizing. These factors lead to a better performance of a family business anywhere in the world.

In line with the findings and the conclusion above, the study thus recommends that successors should equip themselves with the understanding of the business environment and its cycles as well as ensuring that the right people are in charge through careful search and proper placement in strategic positions of the business. This will lead to a better focus thus resulting in improved performance and development of the businesses.

\section{References}

Alderson, J. K. (2011). Understanding the Family Business. New York: Business Expert Press.

Anderson, R. C., Duru, A., \&Reeb, D. M. (2012). Investment Policy in Family Controlled Fims. Journal of banking \& finance, 36(6), 1744-1758. doi:10.1016/j.jbankfin.2012.01.018.

Armstrong M., (2009) Armstrong's Handbook of Human Resource Management Practice. 11th ed. London; Philadelphia.

Bizri, R. (2016). Succession in the Family Business: Drivers and Pathways. International journal of entrepreneurial behaviour\& research, 22(1), 133-154. doi:10.1111/etap.12040, 299312.

Breton Miller, I. L., Miller, D., \&Steier, L. P. (2004). Toward an integrative model of effective FOB succession. Entrepreneurship Theory and Practice, 28(4), 305-328. http://dx.doi/10.1111/j.1540-6520.2004.00047.x

Carlock, R. S., \&Aronoff, C. E. (2001). Strategic Planning for the Family Business: Parallel Planning To Unite the Family and Business. Palgrave Macmillan.

Caroline, S. (2014). http://www.mindtools.com/pages/article/newCDV_40.htm 20 August2014.

Cespedes, F. V., \&Galford, R. M. (2004). Succession and Failure. Harvard Business School Case Study, June. 


\section{International Journal of Social Science and Economic Research}

ISSN: 2455-8834

Volume:05, Issue:09 "September 2020"

Chaimahawong, V.\&Sakulsriprasert, A. (2012b). Family Business Succession and Post Succession Performance: Evidence from thaismes. International Journal of Business andManagement, 8(2). doi:10.5539/ijbm.v8n2p19.

Chaimahawong, V. \&Sakulsriprasert, A. (2013). Family Business Succession and Post Succession Performance: Evidence from Thai SMEs. International Journal of Business and Management; Vol. 8, No. 2; 2013ISSN 1833-3850 E-ISSN 18338119. Published by Canadian Center of Science and Education.

Chaimahawong, V., \&Sakulsriprasert, A. (2012a). Family business succession and post succession performance: evidence from Thai SMEs. International Journal of Business and Management, 8(2), 19.

Chrisman, J. J., Chua, J. H.\& Sharma, P. (1998). Important Attributes Of Successors In Family Businesses: An exploratory Study. Family Business Review, 11(1), 19-34.

Chrisman, J. J., Chua, J. H., \&Litz, R. (2003). A Unified Systems Perspective of Family Firm Performance: An Extension and Integration. Journal of business venturing, 18(4), 467-472. Doi: 10.1016/s0883-9026(03)00055-7.

Chua, H. J., Chrisman, J. J., \& Sharma, P. (1999). Defining the Family Business by Behaviour. Entrepreneurship: Theory and Practice, 23(4), 19-39.

Chua, J. H., Chrisman, J. J., \& Sharma, P. (1999). Defining the Family Business by Behavior. Entrepreneurship Theory and Practice, 23(4), 19-39.

Cisneros, L.\&Deschamps, B. (2015). The Role of Advisors and the Sequence of Their Actions in Sibling Team Succession.M@n@gement, 18(4), 282-308.

Colot, O.\&Bauweraerts, J. (2014). Succession in Family Versus Nonfamily SMEs: What Influence Does It Have On Performance? Canadian Journal of Administrative Sciences (John Wiley \& Sons, Inc.), 31(3), 149-159. doi:10.1002/cjas.1285.

Comi, A., \&Eppler, M. J. (2014). Diagnosing Capabilities in Family Firms: An Overview of Visual Research Methods and Suggestions for Future Applications. Journal of Family Business Strategy, 5, 41-51.

De Massis, A., Chua, J. H. \& Chrisman, J. J. (2008). Factors Preventing Intra-Family Succession. Family Business Review, 21(2), 183-199. Doi.1111/j.17416248.2008.00118.x, http://dx.doi.org/10.1111/j.1741-6248.2008.00118.x 


\section{International Journal of Social Science and Economic Research}

ISSN: 2455-8834

Volume:05, Issue:09 "September 2020"

De Massis, A., Chua, J. H.\& Chrisman, J. J. (2008). Factors Preventing Intra-Family Succession. Family Business Review, 21(2), 183-199. doi:10.1111/j.17416248.2008.00118.x.

Dekimpe, M. G. \&Deleersnyder, B. (2018). Business Cycle Research in Marketing: A Review and Research Agenda. Journal of the Acad. Mark. Sci. (2018) 46:31-58.

Erven, B. L. (2019). Building Family Business Relations. Agricultural Administration Building, Columbus, OH43210, (614) 292 - 6387.

Farrell, M. (2018). Leadership Reflections: Organizational Culture. Journal of LibraryAdministration, 58(8), 861-872. doi: 10.1080/01930826.2018.1516949.

Georgiou, T.\&Vrontis, D. (2013). Wine Sector Development: A Conceptual Framework toward Succession Effectiveness in Family Wineries. Journal of Transnational Management, 18(4), 246-272.

Gopalakrishnan, S. \& Zhang, H. (2017). Client Dependence and Vendor Innovation: The Moderating Role of Organizational Culture. Industrial Marketing Management, 66, 80-89. doi:10.1016/j.indmarman.2017.07.012.

Green, W. \&Cluley, R. (2014). The Field of Radical Innovation: Making Sense of Organizational Cultures and Radical Innovation. Industrial Marketing Management, 43(8), 1343-1350. doi:10.1016/j.indmarman.2014.08.008.

Kanter, R. M. (2009). Supercorp: How Vanguard Companies Create Innovation, Profits, Growth, And Social Good? New York: Crown Publishing Group.

Kirsipuu, M. (2011). Role of Family Business in Estonian Economy.Kirjastajad: BMW * Berliner Wissenschafts-Verlag GmbH, Mattimar OÜ, 2011, pp. 50-68.

Leithy, W. (2017). Organizational Culture and Organizational Life Cycle. International Journal of Economics \& Management Sciences, 06(03). doi: 10.4172/21626359.1000433.

Loiseau, M. D. (2011). Nature and Causes of Job Satisfaction. Handbook of Industrial and Organizational Psychology. Rand McNally, Chicago.

Lu, D. \&Visser, A. (2019). Incumbent Leaders and Their Effect on the Successor Generation in Family Business SME's. Bachelor Thesis Within: Business Administration, International Management. Jönköping University, Jönköping International. 
International Journal of Social Science and Economic Research

ISSN: 2455-8834

Volume:05, Issue:09 "September 2020"

Malinen, P. (2001). Like Father Like Son? Small Family Business Succession Problems in Finland. Enterprise and Innovation Management Studies, 2(3), 195-204. http://dx.doi.org/10.1080/14632440110105053.

Mandl, I. (2008). Overview of family business relevant issues. Vienna: Austrian Institute for SME Research.

McConaughy, D. L. (2000). "Family CEOs Vs Non Family CEOs in the Family Controlled Firm: An Examinations Family Business Review 3, pp. 121-131.

Mohelska, H. \&Sokolova, M. (2015). Organizational Culture and Leadership - Joint Vessels? Procedia - Social and Behavioral Sciences, 171, 1011-1016. doi:10.1016/j.sbspro.2015.01.223.

Poza, E. J., \& Daugherty, M. S. (2013). Family Business (4th ed.). Mason, OH: Cengage Learning.

Reay, T., \& Zhang, Z. (2014). Qualitative Methods in Family Business Research. The SAGE handbook of family business, 573-593.

Sharma, P. \& Sharma, S. (2011) Drivers of Proactive Environmental Strategy in Family Firms. For Publication Consideration in the School Issue of Business.

Stock, J. H. \& Watson, M. W. (1999). Business Cycle Fluctuations in US Macroeconomic Time Series. Handbook of Macroeconomics, Volume 1, Part A, Pp 3-64.

Venter, E., Boshoff, C., \& Maas, G. (2005). The Influence of Successor-Related Factors on the Succession Process in Small and Medium-Sized Family Businesses. Family Business Review, 18(4), 283-303. http://dx.doi.org/10.1111/j.1741$\underline{6248.2005 .00049 .}$

Venter, E., Boshoff, C., \& Maas, G. (2005). The Influence of Successor-Related Factors on the Succession Process in Small and Medium-Sized Family Businesses. Family Business Review.

Wang, C. (2010). Daughter Exclusion in Family Business Succession: A Review of the Literature. Journal of family and economic issues, 31(4), 475484. doi:http://dx.doi.org/10.1007/s10834-010-9230-3 
International Journal of Social Science and Economic Research

ISSN: 2455-8834

Volume:05, Issue:09 "September 2020"

Ye, J., Parris, M. A., \& Waddell, D. (2013). The Succession Decision in ChineseAustralian Family Businesses: An Exploratory Study. Small Enterprise Research, 20(2), 110-125. doi:10.5172/ser.2013.20.2.110.

Zahra, S. A., Hayton, J. C. \&Salvato, C. (2004). Entrepreneurship in family vs. NonFamily Firms: A Resource Based Analysis of the Effect of Organizational Culture. Entrepreneurship Theory and Practice, 28(4), 363-381. 